\title{
Implementation of Techno-Ecopreneurship Worksheet to Train Scientific Literacy Ability among Students in Thermochemistry Topic
}

Rusly Hidayah

The Lecturer of Undergraduate Program of Universitas Negeri Surabaya, Surabaya, Indonesia, ruslyhidayah@gmail.com

\section{Lukjijatul Lutfiana}

An Undergraduate Student of Chemistry Education Program of Universitas Negeri Surabaya, Surabaya, Indonesia, lukjijatullutfiana16030194033@mhs.ac.id

\section{Anggie Bagoes Kurniawan}

An Undergraduate Student of Chemistry Education Program of Universitas Negeri Surabaya, Surabaya, Indonesia, anggiekurniawan16030194077@mhs.unesa.ac.id

\section{Ervina Fadhilatul Ishma}

An Undergraduate Student of Chemistry Education Program of Universitas Negeri Surabaya, Surabaya, Indonesia, ervina.17030194022@mhs.unesa.ac.id

\footnotetext{
The purpose of this research was to describe the learning implementation, students activities, the student's science literacy ability, learning outcame, and response of students to the implementation of techno-ecopreneurship-based student worksheets on thermochemical topic. This research used pre-experimental design with one group pretest-posttest design. The targets of this study were 34 students in XI grade science in Senior High School 3 Sidoarjo. Data collection methods were observation, test, and questionnaire. The research showed the following results: (1) the syntax implementation of guided inquiry learning model is $86.5 \%$ and $88.5 \%$ with a very good category; (2) The activities of students during the learning process were said to be implemented well because the percentage of relevant student activities time is greater compared to the student activities which were not relevant, in which relevant student activity in first meeting was $83.5 \%$ and in second meeting was $90.5 \%$; (3) Student learning outcomes at the pretest $0 \%$ was complete, and $100 \%$ was incomplete but at the posttest $78.78 \%$ is complete and $21.22 \%$ is incomplete; (4) The results of students scientific literacy ability have increased from pretest to posttest that is 18 to 74 with an $\mathrm{N}$-gain value of 0.55 ; (5) Students gave positive responses to the implementation of techno-ecopreneurship-based student worksheet on thermochemical topic to train scientific literacy ability.
}

Keywords: worksheet, techno-ecopreneurship, scientific literacy ability, thermochemical topic

\section{INTRODUCTION}

In the Regulation of Minister of Education and Culture of the Republic of Indonesia Number 22 Year 2016 explained about the learning principles used in the 2013 curriculum that was learning from told to learn become find out (learning of active learners looking to be further strengthened by scientific approaches), learning from verbalism towards applicative skills (Kemendikbud, 2016). Scientific

Citation: Hidayah, R., Lutfiana, L., Kurniawan, A. B., \& Ishma, E. F. (2021). Implementation of TechnoEcopreneurship Worksheet to Train Scientific Literacy Ability among Students in Thermochemistry Topic. Anatolian Journal of Education, 6(1), 17-28. https://doi.org/10.29333/aje.2021.612a 
literacy was one of the skills required in digital age literacy for personal decision-making, participation in civic and cultural affairs, and economic productivity. Scientific literacy was important in modern society since there were many issues related to science and technology (Turiman, et al, 2011). The results of the PISA study for Indonesian students 'scientific literacy according to the OECD report showed that Indonesia's students' scientific literacy ranking in 2012 was ranked $64^{\text {th }}$ out of 65 countries. Science literacy based on PISA 2015 was defined as the ability to explain scientific phenomena, evaluate and design scientific investigations, and interpret scientific data and evidence (OECD, 2013). Science literacy was related to goals of science education, and scientific literacy was related to approaches to achieve scientific literacy (Liu, 2009). This was also supported by the preresearch data of students' scientific literacy abilities conducted by Filayati Ma'ruf Nur (2018) at Senior High School 1 Taman, which showed that one class of 32 students was not completed or $0 \%$ of students who completed when given questions of scientific literacy on thermochemical matter with minimal completeness criteria 78 (Nur, 2018). Student worksheet used by students still did not train the students' scientific literacy ability, because there were only matter and practice exercises in the worksheet (Vienurillah, 2016).

Jespersen, et al. (2012) stated that chemistry was the study of composition, properties, and changes of matter. One of chemistry matter that was able to solve the phenomena that exist in everyday life was thermochemistry. Thermochemistry topic was contextual meaning that the concept of matter could be found in everyday life. According to Gulo (2002) inquiry learning helped teachers to link matter taught with real-world situations. Thus, the learning obtained was more meaningful and the concepts obtained by students were firmly embedded in long-term memory and can increase students' scientific literacy. In addition, students only memorize chemistry matter without understanding its application in daily life so that after changing matter, they forgot what they have learned. Scientific literacy was used variously in one or more of the following ways: (a) Knowledge of the substantive content of science and the ability to distinguish science from nonscience; (b) Understanding science and its applications; (c) Knowledge of what counts as science; (d) Independence in learning science; (e) Ability to think scientifically; (f) Ability to use scientific knowledge in problem solving; (g) Knowledge needed for intelligent participation in science-based social issues; (h) Understanding the nature of science, including its relationships with culture; (i) Appreciation of and comfort with science, including its wonder and curiosity; (j) Knowledge of the risks and benefits of science; or (k) Ability to think critically about science and to deal with scientific expertise (Norris \& Phillips, 2003).

According to Widayoko, et al (2019), 79.03\% of students applied scientific literacy competence in reviewing the issue of the theory. This percentage showed that students used scientific literacy ability in response to science issues. It was expected that with techno-ecopreneurship-based learning, subject topic, namely thermochemistry, could be linked to life phenomena in terms of technology, environment, and economics so as to enhance students' scientific literacy ability. To know the students' scientific literacy through the guided inquiry learning model, an action was needed, one of which was by implementing a techno-ecopreneurship-based worksheet that has been developed by Filayati Ma'ruf Nur (2018) with a content feasibility of 86\%; language feasibility of $80.67 \%$; presentation feasibility was $83.33 \%$ with very fulfilling the criteria. Where the contents in this worksheet include the domain of scientific literacy of students, namely content / knowledge, context, and process / competence.

There were five phase in the syntax of guided inquiry learning model such as (1) Confronting with the problem; (2) Verifying data collection; (3) Collecting experimental data; (4) Organizing and formulating explanations; (5) Analyzing the inquiry process (Joyce, 2009). PISA established three aspects of competence in scientific literacy ability, namely (1) Explaining scientific phenomena; (2) Evaluating and designing scientific investigations; (3) Interpreting data and scientific evidence. The technoecopreneurship-based worksheet contained lessons about technology and ecopreneurship. Technology was the progress of human civilization to facilitate all aspects of life. Ecopreneurship was 
an entrepreneurial concept that was not only profit oriented but also concerned with other aspects, especially environmental aspects (Pradhita, 2013). David Kainhart (2011) revealed that there were three concepts of ecopreneurship, namely: Eco-Innovation, Eco-Opportunity, and Eco-Commitment. Knowledge learning outcomes has been adjusted with the value of minimal completeness criteria. Students' responses were obtained by filling out questionnaire responses.

Based on those some matters, problems were formulated including how the syntax implementation of the guided inquiry learning, the activities of students during the learning process, the scientific literacy ability through the implementation of techno-ecopreneurship-based worksheet, knowledge learning outcomes, and students' responses to the implementation of worksheet on thermochemistry topic. The purpose of this study were to describe the implementation of the syntax of guided inquiry learning, student activities during the learning process, scientific literacy ability through the implementation of techno-ecopreneurship-based worksheet, knowledge learning outcomes, and students' responses to the implementation of techno-ecopreneurship-based worksheet on thermochemistry topic.

\section{METHOD}

This type of research was quantitative descriptive research. The target in this study was students of XI grade in Senior High School 3 Sidoarjo. The research design used was Pre-Experimental Design in the form of One-Group Pretest-Posttest Design (Sugiyono, 2017) in Figure 1.

\begin{tabular}{|c|c|c|c|}
\hline Pretest & Treatment & & Posttest \\
\hline $\mathrm{O}_{1}$ & $\mathrm{X}$ & $\rightarrow$ & $\mathrm{O}_{2}$ \\
\hline
\end{tabular}

Figure 1

One-group pretest-posttest design

Note :

$\mathrm{O}_{1}$ : The initial test was a written test to find out scientific literacy ability and initial knowledge before implementing the techno-ecopreneurship-based worksheet

$\mathrm{X}$ : Treatment by implementing the techno-ecopreneurship-based worksheet

$\mathrm{O}_{2}$ : The final test was a written test to find out scientific literacy ability and learning outcome of students after implementing the techno-ecopreneurship-based worksheet

Learning set used included lesson plan, textbook/handout, student worksheet. The research instruments used included the teacher observation sheet on implementation of learning syntax; student observation sheet; pretest and posttest questions; students' response questionnaire. Data collection methods used were observation, tests and questionnaires. The method of observation was aimed at obtaining data on the implementation of guided inquiry learning syntax and student activity. The test method was aimed at obtaining data on students' scientific literacy ability and students' learning outcomes in thermochemistry topic. Assessment tests of scientific literacy and knowledge learning outcome were given before (pretest) and after (posttest) learning. Data analysis techniques in this study were data analysis of the implementation of learning syntax, student activities, scientific literacy ability, knowledge learning outcome, and response questionnaires. Where the criteria for each data analysis result were described by the research scale (Riduwan, 2016).

Analysis of the implementation of the syntax of guided inquiry learning models aimed to analyze the ability of teacher to manage learning. The implementation of the learning model syntax was obtained from the assessment on the observation sheet by 2 observers in each aspect with a range of scores 1-5. 
Furthermore, the score was converted into data in the form of a percentage. The syntax implementation criteria were shown in Table 1.

Table 1

Syntax implementation criteria

\begin{tabular}{ll}
\hline Score & Category \\
\hline $0 \%-20 \%$ & Very bad \\
\hline $21 \%-40 \%$ & Bad \\
\hline $41 \%-60 \%$ & Medium \\
\hline $61 \%-80 \%$ & Good \\
\hline $81 \%-100 \%$ & Very Good \\
\hline (Adapted from Riduwan, 2016) &
\end{tabular}

Learning could be said to be effective if the teacher in carrying out his learning got a percentage $\geq$ $61 \%$ with good or very good categories.

Analysis of observational data on student activities during learning through guided inquiry learning models was done by knowing the percentage of each activity. The percentage of activity could be calculated as follows:

$\%$ Activity $=\frac{\Sigma \text { the frequency of activity that appears }}{\Sigma \text { the frequency of overall activity }} \times 100 \%$

Figure 2

The formula of the percentage of student activity

Student activities were said to be implemented well if the percentage of relevant student activity time was greater than the activities of students who were not relevant.

Cognitive learning outcomes of students was analyzed with the results of posttest. Student learning outcomes were said to be complete if the posttest scores fulfilled individual completeness scores and classical completeness was determined by Senior High School 3 Sidoarjo on thermochemical matter. Students were said to be complete when learning outcomes $\geq 75$. While classical completeness was calculated using the following formula:

$\%$ Classical completeness $=\frac{\text { the number of students who have completed }}{\text { the total number of students }} \times 100 \%$

Figure 3

The formula of classical completeness

A class was said to be classically complete if $\geq 75 \%$ of all students achieve individual completeness.

The value of scientific literacy was analyzed before and after the implementation of technoecopreneurship-based worksheet by calculating the average difference between the posttest and pretest scores using the $\mathrm{N}$-gain score, which ccould be calculated using the formula:

$\mathrm{N}-$ Gain score $=\frac{\text { posttest score }- \text { pretest score }}{\text { maximum score }- \text { pretest score }}$

Figure 4

The formula of $\mathrm{N}$-gain score

The analysis data of scientific literacy ability before and after the implementation of technoecopreneurship-based worksheet could be shown with N-Gain Score criteria in Table 2 below. 
Table 2

N-gain Score Criteria

\begin{tabular}{ll}
\hline Score & Criteria \\
\hline$g \geq 0,7$ & High \\
\hline $0,7>g \geq 0,3$ & Medium \\
\hline$g<0,3$ & Low \\
\hline (Adapted from Hake, 1998 )
\end{tabular}

Based on the results of this analysis, students were said to have progressed in scientific literacy ability when increasing with medium or high categories.

Data on student responses were analyzed quantitatively descriptive. The analysis was used to find out students' opinions after using the worksheet. The results of the questionnaire responses of students were obtained by giving Guttman scale score as in Table 3 below.

Table 3

Criteria of guttman scale

\begin{tabular}{lll}
\hline Statement & Answer & Score \\
\hline \multirow{2}{*}{ Statement (+) } & Yes (positive response) & 1 \\
\cline { 2 - 3 } & No (negative response) & 0 \\
\hline \multirow{2}{*}{ Statement (-) } & Yes (negative response) & 0 \\
\cline { 2 - 3 } & No (positive response) & 1 \\
\hline
\end{tabular}

(Adapted from Riduwan, 2016)

The percentage of respondents' answers in the questionnaire was calculated using the following formula:

Criteria score $=$ highest score $\mathrm{x}$ number of components $\mathrm{x}$ number of respondents

Percentage $(\%)=\frac{\text { Number of scores from data collection }}{\text { Criteria Score }} \times 100 \%$

Figure 5

The formula of percentage of respondents' answers

Student responses were good or positive to the worksheet that was implemented if the percentage of students' response was $\geq 61 \%$.

\section{FINDINGS AND DISCUSSION}

The results obtained from this research of the implementation of techno-ecopreneurship-based student worksheet on thermochemical topic to train scientific literacy ability would be described as follows:

Implementation of Guided Inquiry Learning Syntax

The data of guided inquiry learning model implementation was obtained from observation by two people using the observation sheet instrument. The implementation of learning in the good category if in the range of percentage of $61 \%$ to $80 \%$ and the category was very good if in the range of percentages $81 \%$ to $100 \%$. The observation result of implementation was presented in Table 4 . 
Table 4

The Observation result of syntax implementation

\begin{tabular}{lllll}
\hline Meeting & Observer & $\begin{array}{l}\text { Score } \\
\text { Obtained }\end{array}$ & Maximum Score & $\begin{array}{l}\text { \% Syntax } \\
\text { Implementation }\end{array}$ \\
\hline $1^{\text {st }}$ & $\mathrm{A}$ & 88 & 100 & $86,5 \%$ \\
\hline$n^{\text {nd }}$ & $\mathrm{B}$ & 85 & 100 & \multirow{2}{*}{$88,5 \%$} \\
\cline { 2 - 5 } & $\mathrm{A}$ & 113 & 124 & \\
\hline
\end{tabular}

The teacher has been able to carry out and overcome the steps of guided inquiry learning model by training students that include the competence to explain scientific phenomena; evaluate data; design scientific investigations; interpret data and scientific evidence. Learning could be said to be effective because the teacher in carrying out learning process gets a percentage of the syntax implementation of $86.5 \%$ (first meeting) and $88.5 \%$ (second meeting) with very good criteria. Gulo (2002) argued that teaching activities with inquiry encouraged the maximum active role of students in the learning process both intellectually and socially emotionally. Therefore, during the learning process, it was important to have maximum student activity.

Techno-ecopreneurship was associated with subject matter in worksheet during the learning process where the teacher explained and encouraged students to associate with the following aspects: (1) Technology: radiator on a motor vehicle as engine coolant; (2) Eco-innovation: critical thinking ability in the process of plant photosynthesis and creative ability in entrepreneurship of ornamental plant who was able to absorb pollutants at home; (3) Eco-opportunity: Identified scientific issues in the form of environmental pollution (air pollutants) and provided recommendations for improvement; (4) Ecocommitment: conducted experiments of exothermic and endothermic reactions honestly and independently. According to David Kainhart (2011), Eco-innovation was an action that contributed to reduce the burden on the environment; eco-opportunities were the ability to take advantage of market failures due to environmental aspects, and eco-commitment was a willingness to work hard, provide energy and time for work or activities that were environmentally friendly.

\section{Student Activity}

Student activity data obtained through the observation of three people with an instrument of student activity observation sheet. Observation was made during the learning activities happened with a period of every five minutes using the guided inquiry learning model. Therefore, during the learning process, it was important to have maximum student activity. Student activities were said to be implemented well because the percentage of relevant student activity time was greater than the activities of irrelevant students where the activities of relevant students at the first meeting was $83.5 \%$ and at the second meeting was $90.5 \%$. Activities were observed in order to find out the activities carried out by students during the learning process using the guided inquiry model. Based on Piaget's theory, the activity of conducting experiment was suitable for 11 years old child to adulthood, which was able to solve problem by using systematic experimentation (Nur, 1998).

There were sixteen aspects observed such as (1) Listening to the teacher's explanation; (2) Observing by reading the application of the matter concepts in daily life (domain context and scientific knowledge); (3) Reading the literature before answering questions; (4) Discussing/answering questions to the teacher/student; (5) Identifying problems (explaining scientific phenomena); (6) Identifying scientific questions (explaining scientific phenomena); (7) Formulating hypotheses (explaining scientific phenomena); (8) Formulating explanatory hypotheses (explaining scientific phenomena); (9) Analyzing the urgency of investigation to be carried out (explaining scientific phenomena); (10) Designing and conducting experiments (evaluating and designing scientific investigation); (11) 
Determining matters that must be considered before conducting experiments (evaluating and designing scientific investigation); (12) Writing observational data (interpreting scientific data and results); (13) Analyzing the results of experiment (interpreting data and scientific evidence); (14) Summarizing the results of experiment and associating matter with phenomena in everyday life (interpreting data and scientific evidence); (15) Evaluating the experimental process and experimental results (evaluating and designing scientific investigations); (16) Irrelevant activity.

\section{Knowledge Learning Outcomes}

The knowledge learning outcomes of students were obtained with the test sheets of learning outcomes given before and after the treatment in the form of multiple choice questions. Individual student learning outcomes were said to be complete if students got a value of $\geq 75$. This value has adjusted the minimal completeness criteria of XI grade students in Senior High School 3 Sidoarjo, which is 75. The recapitulation of knowledge learning outcomes of students from the number of 33 students was presented in Figure 6.

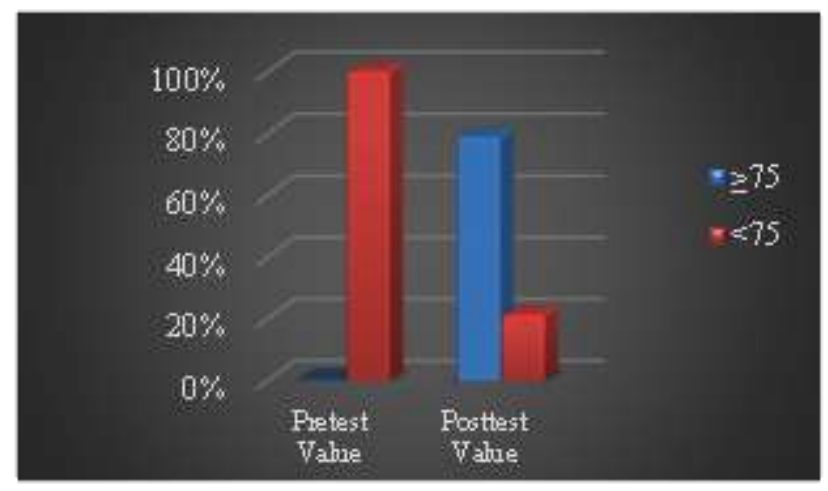

Figure 6

Knowledge learning outcomes graph

Figure 6 showed that the percentage of students' pretest value who got a value of $\geq 75$ was $0 \%$ which showed the initial ability of students. The percentage of students' posttest value who got a value more than or the same as 75 score was $78.78 \%$ with the complete category. This showed that the implementation of techno-ecopreneurship based worksheet on thermochemistry topic could make students better understand concepts, especially systems and environments. Students who have not reached the completeness on the posttest result according to the minimal completeness criteria of Senior High School 3 Sidoarjo was $21.22 \%$. The incompleteness that occured in students was caused by several factors, such as the ability of scientific literacy that was still low; students did not pay attention to the teacher's explanation, and did not carry out the experiment correctly.

\section{Scientific Literacy Ability}

The scientific literacy ability was trained using a techno-ecopreneurship-based worksheet to train science literacy through guided inquiry model that could be measured through pretest and posttest questions include questions of scientific literacy. The test given to students was in the form of essays 5 questions covered two scientific literacy competencies: (1) explaining scientific phenomena, (2) interpreting data and scientific evidence. 
Table 5

Data calculation result of scientific literacy ability

\begin{tabular}{|c|c|c|c|c|}
\hline Numb. & Name & Pretest Value & Posttest Value & N-Gain \\
\hline 1 & ARA & 17 & 70 & 0,53 \\
\hline 2 & $\mathrm{ABS}$ & 17 & 74 & 0,57 \\
\hline 3 & ARD & 13 & 65 & 0,52 \\
\hline 4 & AAZ & 13 & 61 & 0,48 \\
\hline 5 & ANA & 10 & 57 & 0,47 \\
\hline 6 & $\mathrm{AL}$ & 13 & 61 & 0,48 \\
\hline 7 & AEP & 13 & 65 & 0,52 \\
\hline 8 & AFA & 13 & 65 & 0,52 \\
\hline 9 & ANR & 13 & 74 & 0,61 \\
\hline 10 & AAH & 17 & 74 & 0,57 \\
\hline 11 & DFR & 26 & 87 & 0,61 \\
\hline 12 & DRG & 17 & 70 & 0,53 \\
\hline 13 & FRS & 17 & 74 & 0,57 \\
\hline 14 & FPS & 26 & 87 & 0,61 \\
\hline 15 & GSP & 22 & 83 & 0,61 \\
\hline 16 & GKA & 22 & 78 & 0,56 \\
\hline 17 & GTA & 22 & 78 & 0,56 \\
\hline 18 & MYR & 26 & 87 & 0,61 \\
\hline 19 & MAW & 26 & 83 & 0,57 \\
\hline 20 & MFA & 26 & 87 & 0,61 \\
\hline 21 & NBA & 22 & 83 & 0,61 \\
\hline 22 & NRP & 22 & 78 & 0,56 \\
\hline 23 & PI & 13 & 61 & 0,48 \\
\hline 24 & PRN & 13 & 57 & 0,44 \\
\hline 25 & $\mathrm{RPH}$ & 9 & 57 & 0,48 \\
\hline 26 & RRR & 9 & 61 & 0,52 \\
\hline 27 & RFN & 13 & 65 & 0,52 \\
\hline 28 & RPD & 13 & 65 & 0,52 \\
\hline 29 & SR & 22 & 83 & 0,61 \\
\hline 30 & STA & 26 & 91 & 0,65 \\
\hline 31 & TPD & 30 & 91 & 0,61 \\
\hline 32 & WWP & 22 & 78 & 0,56 \\
\hline 33 & YGA & 26 & 87 & 0,61 \\
\hline Average & & 18 & 74 & 0,55 \\
\hline
\end{tabular}

Based on Table 5, the average of pretest value was 18 . That showed that the scientific literacy ability of students in these competencies were still low. Those were because students have not gotten matter about thermochemistry topic. After students get learning process by using techno-echopreneurshipbased worksheet in guided inquiry learning model, the posttest value got better ie the average value obtained was 74 . The increase that occured in these competencies was 0.55 with medium criteria. Based on the results, it could show that students have been trained when in the learning process in answering questions in worksheet in the form of competencies to explain scientific phenomena; and interpret data and scientific evidence so that they really understood and could do posttest questions. Dahar (2011) states that meaningful learning is a process of relating new information to relevant concepts contained in cognitive structures.

There were four competencies that were trained, but only two competencies were assessed in the posttest questions, namely (1) explaining scientific phenomena; and (2) interpreting data and scientific 
evidence. Where from the posttest value obtained, more students could explain scientific phenomena correctly than interpret data and scientific evidence. Interpreting data was such a core activity of all scientists that some rudimentary understanding of the process was essential for scientific literacy. Initially data interpretation began with looking for patterns, constructing simple tables and graphical visualisations such as pie charts, bar graphs, scatterplots or Venn diagrams (PISA, 2013). Student fault in data interpretation due to students' basic understanding of matter concepts that were still low and students' inaccuracy in observing tables. Besides that, it was caused by the inaccuracy of students in reading the statement in the phenomena so that there were some sub answers that were not answered.

\section{Student Responses}

Students' responses were obtained by filling out questionnaire responses by students of class XI Science 3 as many as 33 people. This questionnaire was given to students after implementing the techno-echopreneurship-based worksheet in guided inquiry learning model. In the questionnaire, there were 10 statements with yes or no choice answers relating to the learning process of training students' scientific literacy ability.

Table 6

Data Calculation result of student responses

\begin{tabular}{lll}
\hline Statement & Percentage & Criteria \\
\hline $\begin{array}{l}\text { I agree if the implementation of techno-ecopreneurship-based } \\
\text { worksheet is implemented in schools }\end{array}$ & $93.93 \%$ & Very good \\
\hline $\begin{array}{l}\text { I would be more happy if learning process uses the } \\
\text { implementation of techno-ecopreneurship-based worksheet }\end{array}$ & $96.96 \%$ & Very good \\
\hline $\begin{array}{l}\text { The implementation of techno-ecopreneurship-based } \\
\text { worksheet is useful for me in training science literacy ability }\end{array}$ & $90.90 \%$ & Very good \\
\hline $\begin{array}{l}\text { The implementation of techno-ecopreneurship-based } \\
\text { worksheet to train science literacy ability is interesting to me }\end{array}$ & $93.93 \%$ & Very good \\
\hline $\begin{array}{l}\text { Using techno-ecopreneurship-based worksheet helped me to } \\
\text { more easily understand thermochemistry topic }\end{array}$ & $96.96 \%$ & Very good \\
\hline $\begin{array}{l}\text { I was motivated to learn thermochemistry topic by using a } \\
\text { techno-ecopreneurship-based worksheet }\end{array}$ & $93.93 \%$ & Very good \\
\hline $\begin{array}{l}\text { With the existence of techno-ecopreneurship-based worksheet } \\
\text { to train scientific literacy ability, I can apply thermochemistry } \\
\text { concept in everyday life }\end{array}$ & $84.84 \%$ & Very good \\
\hline $\begin{array}{l}\text { By the implementation of techno-ecopreneurship-based } \\
\text { worksheet to train scientific literacy ability, I use my time } \\
\text { more efficiently to study }\end{array}$ & $90.90 \%$ & Very good \\
\hline $\begin{array}{l}\text { If other subject matter is taught using a techno- } \\
\text { ecopreneurship-based worksheet, I can also understand the } \\
\text { matter easily }\end{array}$ & $93.93 \%$ & Very good \\
\hline I feel that there are obstacles in following this learning & $18.19 \%$ & Very good \\
\hline
\end{tabular}

The data calculation result of student response was presented in Table 6. Based on student response that got the highest percentage of $96.96 \%$, students would be happier if learning using the implementation of techno-ecopreneurship-based worksheet and students were easier to understand thermochemistry topic. Meanwhile those which got the lowest percentage of $18.19 \%$ is that several students still faced obstacles in participating in learning using the techno-ecopreneurship-based worksheet to train scientific literacy. This was appropriate with the opinion of Sanjaya (2014) that the inquiry learning model emphasized the development of cognitive, affective and psychomotor aspects in a balanced way, so that learning was more meaningful. Meaningful learning would facilitate students in understanding the matter being taught. The teacher provided the opportunity for students to 
be more independent in finding concepts and encouraging using their own strategies for learning that were more meaningful. The overall percentage of results from the ten statements that was $91.81 \%$ in the excellent category (very good). The response of students was very good, in this case it showed a positive response indicating that the success of the teacher in implementing the technoecopreneurship-based worksheet with the guided inquiry learning model so that the students felt happy and enthusiastic about the learning conducted. The condition of students who were active, happy and enthusiastic in the learning process, the students would better understand the sub matter presented. In addition, the implementation of techno-ecopreneurship-based worksheet was able to train students' scientific literacy ability.

\section{CONCLUSION AND SUGGESTIONS}

Based on the discussion of research result, it can be concluded as follows:

1. The quality of the learning implementation during two meetings obtained an average score of $86.5 \%$ and $88.5 \%$ which was included in the excellent category (very good). This showed that the teacher has carried out teaching and learning activities in accordance with the syntax of guided inquiry learning model well and has trained the ability of scientific literacy to students well.

2. Student activities were said to be implemented well because the percentage of relevant student activity time is greater than the time of student activities who were not relevant. The relevant student activities at the first meeting was $83.5 \%$ and at the second meeting was $90.5 \%$.

3. Knowledge learning outcomes were processed based on value of pretest and posttest. In the pretest, there were $78.78 \%$ of students who achieved completeness in accordance with the minimal completeness criteria XI grade of Senior High School 3 Sidoarjo which got value $\geq 75$ and $21.22 \%$ of students who had not yet reached completeness.

4. The results of achieving student scientific literacy ability have increased between the results of the pretest and posttest. This was indicated by the average value of pretest result of 18 and posttest of 74 . The increase that occurred in this competency was 0.55 with medium criteria.

5. Students provided a positive response to the implementation of techno-ecopreneurship-based worksheet to train students' scientific literacy ability on thermochemistry matter.

Research that has been carried out by implementing technoecopreneurship-based worksheet to practice scientific literacy ability in science learning has several implications. Technoecopreneurship-based worksheet could be applied to science matter related to technology and environment to provide solutions to problems that occured in the real life. Technoecopreneurship-based worksheet teach science that could be applied in school by adjusting the characteristics of matter.

Based on the results of research conducted, the suggestion that could be given by researchers was that before implementing techno-ecopreneurship-based worksheet, it was better to control the time well so that each syntax of guided inquiry learning can be implemented well. There were some experimental materials that were not provided by school so teacher had to find alternative chemicals that were suitable for thermochemistry experiment. This worksheet only covered two sub-chapters of thermochemistry matter, namely (1) System \& Environment, Heat, and Enthalpy; (2) Exothermic Reaction and Endothermic Reaction so that this research should be further developed for all sections in thermochemistry matter. Teachers should try to develop scientific literacy questions and students should be accustomed in practicing questions that had a framework such as the PISA questions.

\section{REFERENCES}

Dahar, R. W. (2011). Teori-teori Belajar \& Pembelajaran. Jakarta: Erlangga. 
Gulo, W. (2002). Strategi Belajar Mengajar. Jakarta: Grasindo.

Hake, R. R. (1998). Interactive-engagement Versus Traditional Methods: A Six-thousand-student Survey for Mechanics Test Data for Introductory Physics Courses. American Journal of Physics, 66, 64-74.

Jepersen, N. D., \& Brady, J. E. (2002). Chemistry: The Molecular Nature of Matter. New York: John Wiley and Sons.

Joyce, B. (2009). Models of Teaching : Advance Organizer. New Jersey: Pearson.

Kainhart, D. (2011). Ecopreneurship in Theory and Practice : A Proposed Emerging Framework for Ecopreneurship. Saarbrücken: LAP LAMBERT Academic Publishing.

Kemendikbud. (2016). Peraturan Menteri Pendidikan dan Kebudayaan Republik Indonesia Nomor 22 Tahun 2016. Jakarta: Kemendikbud.

Liu, X. (2009). Beyond Science Literacy: Science and the Public. International Journal of Environmental \& Science Education, 4(3), 301-311.

Norris, S. P., \& Phillips, L. M. (2003). How Literacy in Its Fundamental Sense Is Central to Scientific Literacy. Science Education, 224-240.

Nur, F. M. (2018). Development of Student Worksheet Based Guided Inquiry to Practice Scientific Literacy in Thermochemical Chapter of XI Grade in Senior High School. Advances in Engineering Research, 141, 147-150.

Nur, M. (1998). Teori-Teori Perkembangan. Surabaya: Unipress UNESA.

OECD. (2013). Draft Science Literacy Framework 2015. Paris: OECD Publishing.

PISA. (2013). PISA 2015 Draft Science Framework. Perancis: OECD. Retrieved from http://www.oecd.org/pisa/pisaproducts/pisa2015draftframeworks.htm

Pradhita, T. (2013). Kajian Implementasi Aspek-Aspek Ecopreneurship Pada Bisnis Bidang Fashion. Bandung: Universitas Telkom.

Riduwan. (2016). Skala Pengukuran Variabel - Variabel Penelitian. Bandung: Alfabeta.

Sanjaya, W. (2014). Strategi Pembelajaran Berorientasi Standar Proses Pendidikan. Jakarta: Prenada Media Group.

Sugiyono. (2017). Metode Penelitian Kuantitatif Kualitatif dan R\&D. Bandung: Alfabeta.

Turiman, P. O. (2011). Fostering the 21st Century Skills through Scientific Literacy and Science Process Skills. Procedia-Social and Behavioral Sciences, 59, 110-116.

Vienurillah, N., \& Dwiningsih, K. (2016). Pengembangan Lembar Kegiatan Peserta didik (LKS) berorientasi Literasi sainsnpada submateri faktor-faktor yang mempengaruhi laju reaksi. Unesa Journal of Chemical Education, 5(2), 258-263. 
Widayoko, A., Femilia, P. S., Lesmono, A. D., Sudjatmi, H., Prastiwi, V. D., \& Munfarikha, N. (2019). Description of Students' Scientific Literacy Competencies on the Scientific Issue of Flat Earth Theory. Anatolian Journal of Education, 4(2), 31-38. 